\section{KINETICS, \\ EQUILIBRIUM \\ MECHANISMS OF NI (II) AND Pb (II) ION BIOSORPTION USING BIOSORBENT MIXTURE OF RHIZOPHORA APICULATE SP. AND ELAEIS GUINEENSIS SP.}

M. B. Nicodemus Ujih, Mohammad Isa Mohamadin*, MillaaArmila Asli, Bebe Norlita Mohamed

Faculty of Applied Science, Universiti Teknologi MARA Sarawak, Campus Samarahan 2, 94300 Kota Samarahan, Sarawak, Malaysia
Article history

Received

4 February 2018

Received in revised form

13 August 2018

Accepted

20 August 2018

Published online

15 December 2018

*Corresponding author misa@sarawak.vitm.edu.my

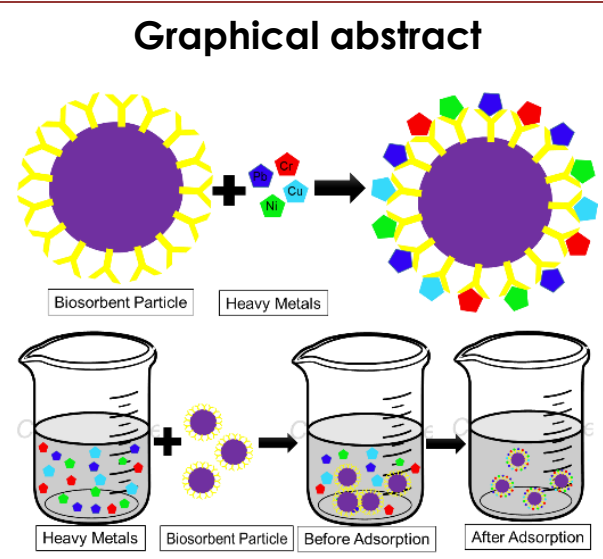

\begin{abstract}
The existence of metal ions in water supply has become a severe issue and created an awareness of the important of finding the significant methods for the removal of heavy metals (HM). In this study, the biosorbent used are Oil Palm Mesocarp Fibe (OPMF) (Elaeis guineensis sp.) and Mangrove Bark (Rhizophora apiculate sp.). These biosorbents are mixed to form the biosorbent mixture (BM) to enhance the biosorption performance towards $\mathrm{Ni}$ (II) and $\mathrm{Pb}$ (II) ions. Four parameters applied to investigate the biosorption performance, i.e. reaction time, ratio/dosage, initial concentration and $\mathrm{pH}$ values. The biosorption performance for $\mathrm{Pb}$ (II) $(90 \%, 5.7 \mathrm{mg} / \mathrm{g})$ was higher than $\mathrm{Ni}$ (II) $(55 \%, 3.9 \mathrm{mg} / \mathrm{g})$. Five kinetic models were exercised to investigate the kinetic mechanisms namely pseudo-first and second-order, Bangham's theory, intra-particles diffusion and Elovich equation. The isotherm models i.e Langmuir, Freundlich, Dubinin-Radushkevich and Temkin Isotherm are exercised to analyse the equilibrium biosorption data. Overall, the pseudosecond-order discovered to act as biosorption kinetics for both $\mathrm{Ni}$ (II) and Pb (II) ions. The equilibrium biosorption data of $\mathrm{Pb}$ (II) follows Temkin Isotherm, and the Ni (II) supported by the Freundlich Isotherm.
\end{abstract}

Keywords: Rhizophora apiculate sp., Elaeis guineensis sp., heavy metals, biosorbent, biosorption

\begin{abstract}
Abstrak
Kewujudan logam berat dalam air telah menjadi isu hangat dan menimbulkan kesedaran dalam mencari jalan penyelesaian untuk menyahkan logam berat. Dalam penyelidikan ini, biomass seperti kulit kayu bakau dan buah kelapa sawit telah digunakan. Kedua-dua biojisim ini dicampurkan untuk membentuk Campuran Penjerap (BM) untuk meningkatkan prestasi penjerapan. Empat faktor penting untuk mengenalpasti prestasi penjerapan iaitu masa tindak balas, kepekatan awal, nisbah/dos dan $\mathrm{pH}$ awal. Prestasi penjerapan untuk $\mathrm{Pb}$ (II) $190 \%$, $5.7 \mathrm{mg} / \mathrm{g}$ ) adalah lebih besar daripada Ni (II) $(55 \%, 3.9 \mathrm{mg} / \mathrm{g})$. Lima kinetic model telah digunakan untuk menyiasat mekanisme kinetic seperti pseudofirst-order and second-order, Bangham's theory, intra-particles diffusion and Elovich equation. Model isotherm seperti Langmuir, Freundlich, DubininRadushkevich (D-R) dan Temkin Isotherm juga telah digunakan untuk menganalisis data penjerapan keseimbangan. Keseluruhannya, pseudosecond-order telah bertindak sebagai penjerapan kinetik untuk Ni (II) and $\mathrm{Pb}$ (II) ions. Selain itu, $\mathrm{Pb}$ (II) ditemui mengikuti Temkin Isotherm dalam data penjerapan keseimbangan manakala Ni (II) mengikuti Freundlich isotherm.

Kata kunci: Rhizophora apiculate sp., Elaeis guineensis sp., logam berat penjerap, penjerapan
\end{abstract}

(C) 2019 Penerbit UTM Press. All rights reserved 


\subsection{INTRODUCTION}

Metal ions pollution in wastewater has become a severe environmental issue and has caught the attention of the World Health Organisation (WHO) to find efficient ways to remove metal ions. The nondegradable and chemical properties of metal ions that are very toxic as well as its accumulation in the living cell can cause severe effects on organisms especially human, which can even cause death [1,2]. These metal ions were found to be originated from industrial areas where the wastewater discharged into any body of water without any treatment $[3,4,5]$.

Currently, traditional method are being used to remove metal ions by using several mechanisms, i.e. chemical precipitation, ion exchange and electrocoagulation $[1,6,7]$. Unfortunately, this method was found to be unsuitable due to high cost and non eco-friendly [8]. Nevertheless, Macek et al. [9] and Das et al. [10] claimed that metal ions removal via biomass has provided more advantages as it is the cheapest and has the highest biosorption performance. In this research, the biomasses of mangrove bark (MB) and oil palm mesocarp fibre (OPMF) are proven to have high tendency in adsorbing metal ions. The aims of this research are to investigate the biosorption performance of $\mathrm{Ni}$ (II) and $\mathrm{Pb}$ (II) on biosorbent that includes the equilibrium and kinetic biosorption, and factors that influence in the biosorption performance.

\subsection{METHODOLOGY}

\subsection{Materials}

The raw materials, mangrove logs (Rhizophora apiculate sp.), were obtained from Santubong Mangrove National Park, Sarawak, Malaysia. While, the oil palm fruit bunches (Elaeis guineensis sp.) were collected from Ensengei Palm Oil Plantation, Kota Samarahan Sarawak. Both of these samples were collected directly from the sampling sites to ensure the exact species, freshness, and ease of experimentation.

\subsubsection{Pre-treatment of Raw Materials}

$M B$ was isolated from the mangrove logs and washed thoroughly with tap water to discard any insoluble impurities and dirt's from the sample. The raw samples were dried in the oven at $70^{\circ} \mathrm{C}$ overnight before it is grounded and sieved to a particle size of $250-300 \mu \mathrm{m}$ mesh. The sample was later soaked in $37 \%$ Formaldehyde and 0.1M Sodium Hydroxide ( $\mathrm{NaOH})$ for two hours at $50^{\circ} \mathrm{C}$ and then rinsed thoroughly with deionised water. The sample was kept in an airtight container after it is left to dry overnight at $65^{\circ} \mathrm{C}$.

The outer layers of the oil palm fruit were peeled off to separate the kernel from the shell and immersed in hot deionised water with detergent for 4-5 hours to remove the oil from the fibres. OPMF was dried in an oven overnight at $50-60^{\circ} \mathrm{C}$ and grounded into smaller fibres size and sieved into $250-300 \mu m$ mesh. The raw samples were chemically treated with $0.2 \mathrm{M}$ nitric acid $\left(\mathrm{HNO}_{3}\right)$ solution. After five hours, the samples were rinsed with the excess deionised water, filtered and kept in an airtight bottle after it is left to dry at $60^{\circ} \mathrm{C}$ for a night.

\subsection{Heavy Metals Solution}

All the reagents used for this study were analytical grade and purchased from Merck. The lead and nickel standards solution were prepared from $1000 \mathrm{mg} / \mathrm{L}$ of a pure standard stock solution, $\mathrm{Pb}\left(\mathrm{NO}_{3}\right)_{2}$ and $\mathrm{Ni}\left(\mathrm{NO}_{3}\right)$, respectively by the dilution factor technique. Both of heavy metals with the molecular weight of $58.693 \mathrm{~g} / \mathrm{mol}$ (Nickel) and $207.2 \mathrm{~g} / \mathrm{mol}$ (Lead) standard solution were diluted in the volumetric flask at a varied initial concentration (25, $20,15,10$ and $5 \mathrm{mg} / \mathrm{L}$ ).

Approximately, $25 \mathrm{ml}$ of each heavy metals standards solution was filled into a $1000 \mathrm{ml}$ volumetric flask to obtain $25 \mathrm{mg} / \mathrm{L}$ and then dilute it with ultrapure water until calibration mark. The dilution method was repeated for all other initial concentrations, i.e. 5 , 10, 15 and $20 \mathrm{mg} / \mathrm{L}$. Various parameters were conducted, i.e. dosages/ratios, initial $\mathrm{pH}$ values, contact times and initial concentrations.

The optimization of parameter were analysed using Atomic Absorption Spectroscopy (AAS). Both standard solutions before and after the biosorption process were filtered to separate biosorbent from solution before it was analysed it using AAS. Meanwhile, the functional groups analysis for both biosorbent samples before and after biosorption process were measured by using ATR method in Fourier Transform Infrared (FTIR). Scanning Electron Microscopy (SEM) and X-ray Diffraction (XRD) were used to analysed surface area and the present of heavy metals on surfaces for both samples before and after the biosorption process.

\subsection{Batch Biosorption Experiment}

\subsubsection{Effect of Ratio of Dosage and Initial pH}

The ratio is an essential parameter in biosorption process especially when it involves two types of biomass to examine the optimal ratio that gives better biosorption performance. In this case, five sets of ratios were chosen, namely 90:10, 70:30, 50:50, 30:70 and 10:90 of MB: OPMF. These biomasses were weighted in $100 \mathrm{ml}$ of the conical flask with a maximum 0.2 gram of dosage. Then, $50 \mathrm{ml}$ of $10 \mathrm{mg} / \mathrm{L}$ was filled into the flask after the $\mathrm{pH}$ condition has been adjusted to $\mathrm{pH} 5$ using Sodium Hydroxide $(\mathrm{NaOH})$. The optimum $\mathrm{pH}$ condition was carried out at 0.2 gram of dosage (ratio of 0.18:0.01, OPMF: MB) that contained $50 \mathrm{ml}$ of $10 \mathrm{mg} / \mathrm{L}$ by varying the initial $\mathrm{pH}$ value from $\mathrm{pH} 1$ until $\mathrm{pH}$ 13. This is because based on previous study, some of the heavy metals has higher adsorption at lower $\mathrm{pH}$ than higher $\mathrm{pH}$.

\subsubsection{Effect of Ratio of Reaction Time and Initial Concentration}

These experiments were carried out in acidic condition ( $\mathrm{pH}$ 5) with 0.2 gram of dosage (optimum ratio) in a conical flask containing $50 \mathrm{ml}$ of different concentrations ranging from 5 to $25 \mathrm{mg} / \mathrm{L}$ at varying 
reaction time, viz. 5 to 180 minutes. After the agitation at $250 \mathrm{rpm}$ for 60 minutes, the metal solutions were filtered to isolate the biosorbent particle from the metals solution. All of these effects of experiment were triplicated and agitated for 60 minutes at $250 \mathrm{rpm}$.

\subsection{Estimation of Metal Biosorption}

The biosorption capacity of $\mathrm{Pb}$ (II) and $\mathrm{Ni}$ (II) ions by biosorbent mixture $(\mathrm{mg} / \mathrm{g})$ at equilibrium time and removal efficiency (\%) were examined through the following equations (1) and (2) respectively:

$$
\begin{aligned}
& \mathrm{Q}=\frac{\mathrm{V}\left(\mathrm{C}_{\mathrm{i}}-\mathrm{C}_{\mathrm{e}}\right)}{\mathrm{m}} \\
& \mathrm{Q}_{\mathrm{e}}=\frac{\left(\mathrm{C}_{\mathrm{i}}-\mathrm{C}_{\mathrm{e}}\right)}{\mathrm{C}_{\mathrm{i}}} \times 100 \%
\end{aligned}
$$

Where $Q$ is biosorption capacity $(\mathrm{mg} / \mathrm{g}), Q_{e}$ is biosorption efficiency (\%); $C_{i}$ and $C_{f}$ represent the initial and final initial concentration of metal ions solution (mg/L) respectively. Meanwhile, $V$ is the volume of metals solution (L), and $m$ is the weight of Biosorbent Mixture (BM) used (g).

\subsection{RESULTS AND DISCUSSION}

\subsection{Fourier Transmission Infrared (FTIR)}

Figure 1 illustrates the differences in the spectrum of BM before and after the biosorption process. The Functional groups that were present in the biosorbent are as shown in Table 1. These functional groups played an essential part and acted as active sites in the biosorption process [11, 12]. Most of the spectrum bands appeared before the biosorption were found to reduce in intensity and even completely disappeared after the biosorption (Figure 1). The functional groups lost their chemical identity as the outcome of the interaction with metal ions.

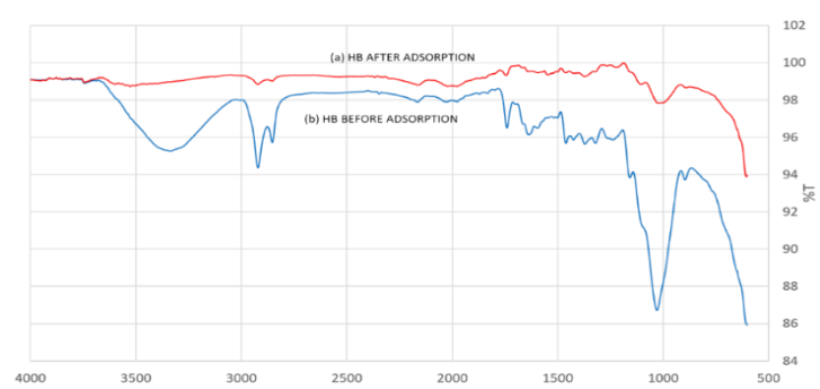

Figure 1 FTIR of Biosorbent Mixture (BM) after (a) and before (b) Heavy Metal Biosorption

Table 1 Functional Group Presence in Biosorbent Mixture (BM)

\begin{tabular}{ccc}
\hline Peak (cm-1) & Functional Group & References \\
\hline $3200-3400$ & hydroxyl group & {$[14,15]$} \\
\hline $2919-2924$ & $-\mathrm{CH}$ alkane group & {$[14,14,15,17]$} \\
$2840-2890$ & $-\mathrm{CH}_{2}$ alkane group & \\
1620, & $\mathrm{C}=\mathrm{C}$ in carbonyl group \\
1670 & $\mathrm{C}=$ O in carbonyl group \\
1780 & $\mathrm{C}-\mathrm{O}$ in carbonyl group \\
$1240-1390$ & carboxyl group \\
\hline $1000-1100$ & $\begin{array}{c}\text { carbonyl group } \\
\text { aromatic group }\end{array}$ \\
1185 & $\begin{array}{c}\text { C-H bond in the } \\
\text { phenolic ring }\end{array}$ \\
&
\end{tabular}

\subsection{Scanning Microscope Spectroscopy Physical} Characteristics

The differences between the external surfaces of biosorbent of MB and OPMF before and after biosorption process is shown in Figure 2 . The unoccupied pores is visible on both biosorbent surfaces (Figure 2(a) and 2(c)) which represent the active sites. As seen in Figure $2(b)$ and $2(d)$, the pores on the surfaces were fully occupied with metal ions after the biosorption process, which prove the biosorption surface properties of MB and OPMF, and met an agreement with the FTIR spectrum analysis.

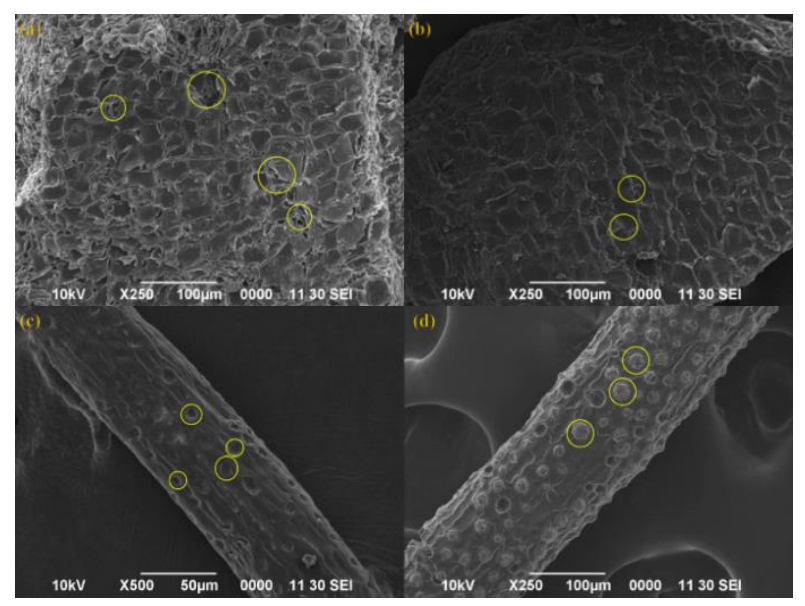

Figure 2 SEM images of MB before (a) and after (b) and OPMF before (c) and after (d) Biosorption Process

\subsection{X-ray Diffraction (XRD) Physical Characteristics}

X-ray diffraction (XRD) technique is a great technique to analyse the presence of crystalline and amorphous nature of the biomass. The sharp peaks indicates the crystalline nature whereas, amorphous material is represented by the broad peaks. Figure 3 shows a well defined peaks in the diffactogram after biosorption process compared with before the biosorption process [13]. This indicates that crystalline nature compounds diffused into mesopores of BM due to the presence of several crystalline peaks such as peak at $2 \theta 45^{\circ}, 62^{\circ}$ and $78^{\circ}$. The peaks at $2 \theta 16.5^{\circ}, 24^{\circ}$ and $35^{\circ}$ is the amorphous peaks. This XRD diffractogram is important to support surface analysis by SEM.

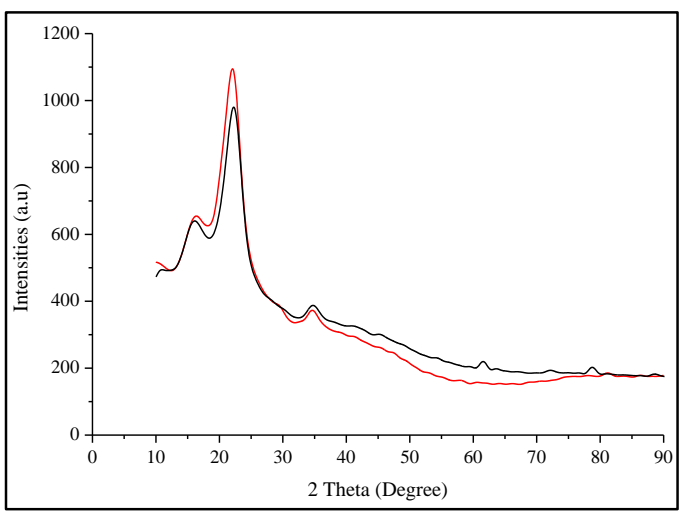

Figure 3 XRD of Biosorbent Mixture Sample After the Biosorption 


\subsection{Effect of Ratio}

As shown in Figure 4, the ratio of 10:90 (MB: OPMF) was the best ratio which gave the highest biosorption performance for $\mathrm{Pb}$ (II) and $\mathrm{Ni}$ (II) ions. The results showed that the biosorption performance for both metal ions slightly declined as the quantity of $M B$ (ratio) increased. This is due to the biosorption performance which was directly dependent on a number of active sites where the sample of OPMF fibre was lighter than $M B$, thus, giving more particles specimens per unit gram [3, 13, 19].

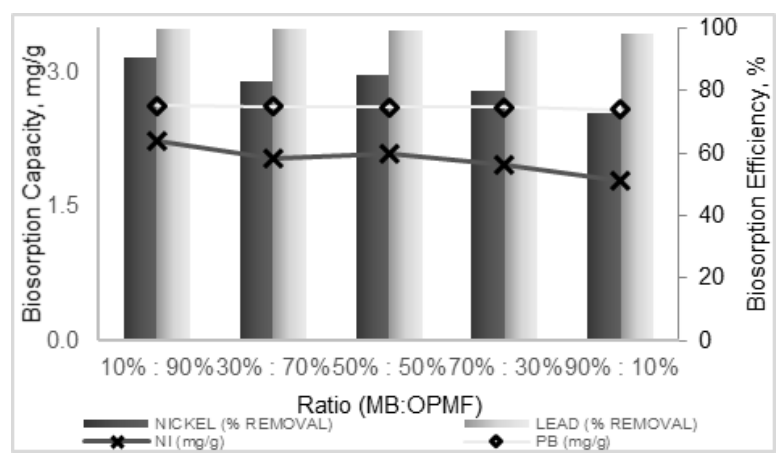

Figure 4 Heavy Metals Biosorption on Ratio as Parameter by Biosorbent Mixture (MB: OPMF) under Constant Dosage of $0.2 \mathrm{~g}$ and $10 \mathrm{mg} / \mathrm{L}$ of Initial Concentration

\subsection{Kinetic Model}

According to the founder Lagergren, the pseudo-firstorder assumed the rate of physical biosorption is directly dependant on the availability of the active sites [20]. The pseudo-first-order linear equation (4) that is derived from equation (3) is as shown below:

$$
\begin{aligned}
& \frac{d Q_{t}}{d t}=k_{1}\left(Q_{e}-Q_{t}\right) \\
& \log \left(Q_{e}-Q_{\mathrm{t}}\right)=\log Q_{\mathrm{e}}-\left(\frac{\mathrm{k}}{2.303}\right) \mathrm{t}
\end{aligned}
$$

Where $Q_{e}$ (mg/g), $Q_{t}(\mathrm{mg} / \mathrm{g})$ and $\mathrm{k}_{1}$ (1/min) are biosorption capacity at equilibrium and at a time ( $t$ ), and the rate constant of pseudo-first-order (Figure $5(a))$ respectively. The value of $k_{1}$ obtained from the slope of a graph $\log \left(Q_{e}-Q_{t}\right)$ versus $t$ (minutes). Meanwhile, pseudo-second-order illustrated that biosorption processes were based on chemical reaction when the polar of functional groups acted as chemical bonding agents, i.e. aldehydes, ketones, ester, alcohol and phenolic hydroxides acid [21]. Equation (5) is the pseudo-second-order expression:

$$
\frac{1}{Q_{t}}=\frac{1}{k_{2} Q_{e}^{2}}+\frac{1}{Q_{e}}
$$

The rate constant of second-order, $k_{2}$, can be acquired from the plots of $t / Q_{t}$ versus $t$ (minutes) (Figure $5(\mathrm{~b})$ ), where the experiment of varying reaction times was conducted at room temperature to determine the optimum reaction times when biosorption reached equilibrium.

Table 2 illustrates the results of pseudo-first and second order kinetics in describing the biosorption process of $\mathrm{Pb}$ (II) and $\mathrm{Ni}$ (II) ions onto the BM. Compared with the pseudo-first-order (Figure 5(a)), pseudo-second-order (Figure 5(a)) which showed the linear regression of $\mathrm{R}^{2}$ values have been found to be 1.000 (Table 2). The values indicated that the chemisorption mechanisms were involved in biosorption process. Furthermore, the calculated values of equilibrium biosorption capacity, $Q_{e}$, for pseudo-second-order has met a good agreement with the experimental values of $Q_{e}$.

Elovich equation is one of the most suitable models to illustrate that the rate of controlling steps is chemisorption process [22]. The linear equation of Elovich theory is as shown below (6):

$$
\mathrm{Q}_{\mathrm{t}}=\left(\frac{1}{\beta}\right) \ln (\alpha \beta)+\frac{1}{\beta} \ln t
$$

Where a $(\mathrm{mg} / \mathrm{g}$ h) represent the initial biosorption rate and $\beta(\mathrm{g} / \mathrm{mg})$ indicates the extent of surface coverage and the activation energy for chemisorption (Georgieva et al., 2015; Tan et al., 2009) respectively. The $1 / \beta$ and $\left(\frac{1}{\beta}\right) \ln (\alpha \beta)$ refer to the number of free active sites and the quantity of the metal ions adsorbed when $\mathrm{In} t$ is equal to zero value [22]. These rate constants can be verified from the slope and c-intercept of the graph $Q_{t}$ vs $\ln$ t. Figure $5 c$ shows the linear plots for $\mathrm{Ni}$ (II) and $\mathrm{Pb}$ (II) ions at 20 $\mathrm{mg} / \mathrm{L}$ initial concentrations. As mentioned in Table 2 the $R^{2}$ values are mostly above 0.90 which indicated the involvement of chemisorption mechanism. The chemisorption rate was constant, $a$ and activation energy, $\beta$ decreased as the initial concentration increased.

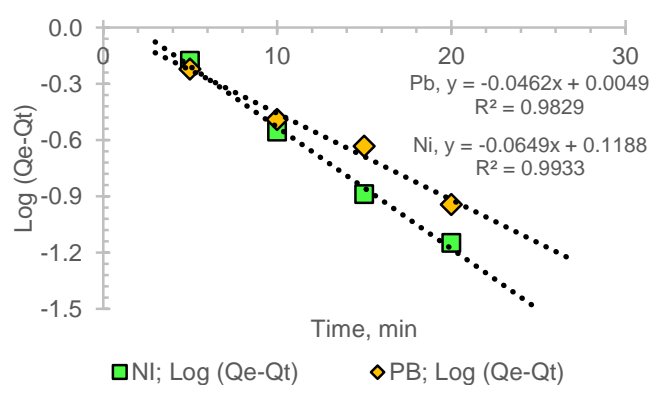

Figure 5(a) Kinetic Study of Pseudo-First-Order of $\mathrm{Pb}(\mathrm{II})$ and $\mathrm{NI}(I I)$ ions for $20 \mathrm{mg} / \mathrm{L}$

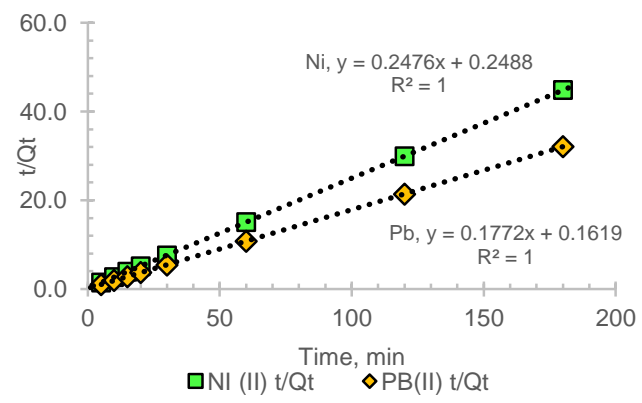

Figure 5(b) Kinetic Study of Pseudo-Second-Order of $\mathrm{Pb}$ (II) and $\mathrm{NI}(\mathrm{II})$ ions for $20 \mathrm{mg} / \mathrm{L}$

The availability of active sites that is lower than the number of metal ions caused the slowing down the rate of biosorption [23]. Furthermore, the $\mathrm{R}^{2}$ value for Elovich was slightly lower than pseudo-second-order. However, the values were still high enough to support the assumption that chemisorption process was the main rate of controlling mechanism in the heterogeneous layer.

Intra-particles diffusion proposed by Weber and Morris is the theory that is entirely different from other kinetic studies as it is used to identify the diffusion 
mechanism involved in biosorption process [15, 22]. The intra-particles diffusion equation is presented as below (7):

$$
Q_{t}=k_{i} t^{\frac{1}{2}}+C_{i}
$$

Where $\mathrm{k}_{\mathrm{i}}(\mathrm{mg} / \mathrm{g} \mathrm{minl/2)}$ is the rate constant of intraparticles diffusion and $C_{i}$ is the c-intercept, which is obtained from the slope of $Q_{\uparrow}$ versus $t^{1 / 2}$ (minutes).

The graph will be linear and passing through the origin if intra-particle diffusion occurred; otherwise, other mechanisms like external surface biosorption or instantaneous biosorption [14] may be involved in the biosorption processes. Figure 5(d) showed that the linear lines did not pass through the origin which indicated that other mechanisms were involved in heavy metal biosorption. The $\mathrm{C}_{\mathrm{i}}$ value indicated the thickness of the boundary layer where the higher value would give a larger effect to the boundary layer [20]. They described that the intra-particle diffusion involved three processing steps, namely external surfaces biosorption, intra-particles diffusion control and equilibrium steps.

Firstly, the external surface biosorption also known as film diffusion is a process that involves the distribution of heavy metal cations on the external surfaces until they are fully occupied with metal ions. Then, the remaining metal ions are move into the pores of biosorbent particles [20]. Lastly, the equilibrium state occurred when the free and remaining of metal ions are slowly adsorbed on the surfaces due to the low concentration of metal ions and active sites. A steady drop in biosorption diffusion and capacity after the surface diffusion mechanism indicates the movement of metal ions that is controlled by pore diffusion [24].

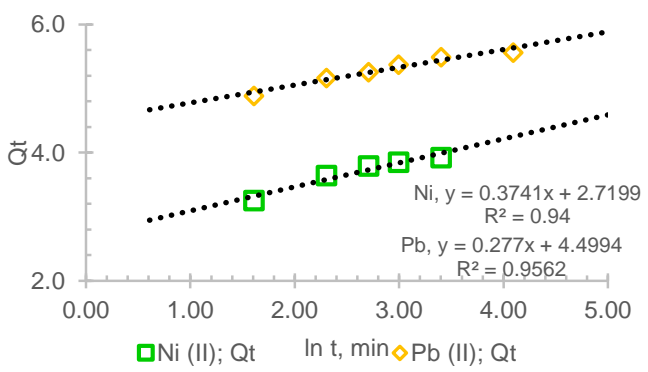

Figure 5(c) Kinetic Model Study of Elovich Equation for $\mathrm{Pb}$ (II) and $\mathrm{Ni}(\mathrm{II})$ ions at $20 \mathrm{mg} / \mathrm{L}$

As shown in Table 2, the Kpi and $C$ values were increased with the increase of initial concentration from 10 to $20 \mathrm{mg} / \mathrm{L}$. These values showed that the thickness of the boundary layer during the biosorption process in $20 \mathrm{mg} / \mathrm{L}$ is thicker than $10 \mathrm{mg} / \mathrm{L}$.
Table 2 The comparison between Kinetics rate constants for $\mathrm{Pb}$ (II) and $\mathrm{Ni}(\mathrm{II})$ ions at 10 and $20 \mathrm{mg} / \mathrm{L}$

\begin{tabular}{|c|c|c|c|c|}
\hline \multirow{2}{*}{$\begin{array}{c}\text { Initial Conc. } \\
\text { Metal ions }\end{array}$} & \multicolumn{2}{|c|}{$10 \mathrm{mg} / \mathrm{L}$} & \multicolumn{2}{|c|}{$20 \mathrm{mg} / \mathrm{L}$} \\
\hline & $\mathrm{Ni}(\mathrm{II})$ & $\mathrm{Pb}(\mathrm{II})$ & $\mathrm{Ni}(\mathrm{II})$ & $\mathrm{Pb}(\mathrm{II})$ \\
\hline $\begin{array}{c}\text { Initial Conc. } \\
\text { (mg/L) }\end{array}$ & 9.8676 & 10.364 & 22.778 & 23.013 \\
\hline$Q_{e}, \exp (\mathrm{mg} / \mathrm{g})$ & 2.3200 & 2.5772 & 3.9224 & 5.4885 \\
\hline \multicolumn{5}{|c|}{ Pseudo-First-Order } \\
\hline$Q_{e}$, cal (mg/g) & 0.7413 & 0.2627 & 1.3146 & 1.0113 \\
\hline$K_{1}\left(\min ^{-1}\right)$ & 0.1898 & 0.1375 & 0.1495 & 0.1064 \\
\hline$R^{2}$ & 0.9925 & 0.9547 & 0.9933 & 0.9829 \\
\hline \multicolumn{5}{|c|}{ Pseudo-Second-Order } \\
\hline$Q_{e}$, cal (mg/g) & 2.3370 & 2.5806 & 4.0388 & 5.6433 \\
\hline$K_{2}\left(\min ^{-1}\right)$ & 0.4268 & 2.11 & 0.2464 & 0.1939 \\
\hline $\mathbf{R}^{2}$ & 1.0000 & 1.0000 & 1.0000 & 1.0000 \\
\hline \multicolumn{5}{|c|}{ Intra-particles Diffusion } \\
\hline $\begin{array}{c}k_{p i} \\
\left(\mathrm{mg} / \mathrm{g} \text { min- }^{-0.5}\right)\end{array}$ & 0.0240 & 0.0067 & 0.0476 & 0.0531 \\
\hline C & 2.310 & 2.508 & 3.5036 & 5.0285 \\
\hline$R^{2}$ & 0.6232 & 0.4924 & 0.5473 & 0.6891 \\
\hline \multicolumn{5}{|c|}{ Pore Diffusion (Bangham's Theory) } \\
\hline $\mathrm{k}_{\mathrm{b}}(\mathrm{ml} / \mathrm{g} / \mathrm{L})$ & 107.23 & 238.51 & 64.25 & 85.09 \\
\hline$a$ & 0.338 & 0.696 & 0.091 & 0.537 \\
\hline$R^{2}$ & 0.9355 & 0.8128 & 0.7998 & 0.9732 \\
\hline \multicolumn{5}{|c|}{ Elovich Equation } \\
\hline a (mg/g min) & 446.12 & $6.67 \times 10^{8}$ & 159.13 & $1.11 \times 10^{5}$ \\
\hline$\beta(\mathrm{mg} / \mathrm{g})$ & 4.706 & 9.960 & 2.282 & 2.919 \\
\hline$R^{2}$ & 0.9995 & 0.9223 & 0.9709 & 0.9899 \\
\hline
\end{tabular}

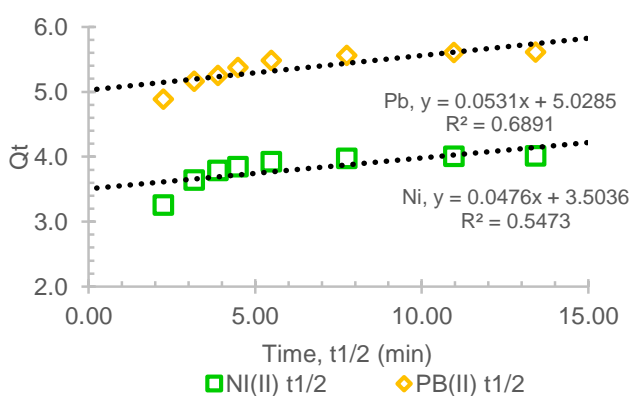

Figure 5(d) Kinetic Study of Intra-particle Diffusion for $\mathrm{Pb}(\mathrm{II})$ and $\mathrm{Ni}(\mathrm{II})$ ions at $20 \mathrm{mg} / \mathrm{L}$

The Bangham's theory assumes that pore diffusion mechanism might be involved in biosorption process of metal ions by checking the kinetic data using Bangham's equation (8).

$$
\log \left(\frac{C_{i}}{C_{i}-C_{s} Q_{t}}\right)=\log \left(\frac{k_{b} C_{s}}{2.303 V}\right)+\alpha \log t
$$

Where $C_{i}$ and $C_{s}$ indicate the initial concentration ( $\mathrm{mg} / \mathrm{L})$ and the amount of dosage used per litre solution ( $\mathrm{g} / \mathrm{L}$ ) respectively. While $V$ is the volume of standard metals solution (ml) and $Q_{t}$ is the biosorption capacity at a time $(\mathrm{mg} / \mathrm{g})$. Constant $\alpha(\alpha<1)$ and $\mathrm{kb}$ 
values can be obtained from the c-intercept and slope of the straight line of log $\left(C_{i} / C_{i}-C_{s} Q_{t}\right)$ versus log $\dagger$ (Figure 5(e)) [24]. As can be seen from Table 2, the constant values of $\alpha$ and $\mathrm{kb}$ for $\mathrm{Ni}$ (II) and $\mathrm{Pb}$ (II) decreased with the initial concentration increase from 10 to $20 \mathrm{mg} / \mathrm{L}$ respectively. This was due to the mass transfer driving force became larger as the initial concentration increased, hence resulting in the higher biosorption performance. It can be seen from Table 1 that the correlation coefficient, $\mathrm{R}^{2}$ for $\mathrm{Pb}$ (II) metal ions increased as the initial concentration increased. The good $R^{2}$ values indicate that the pore diffusion mechanism occurred during the biosorption processes.

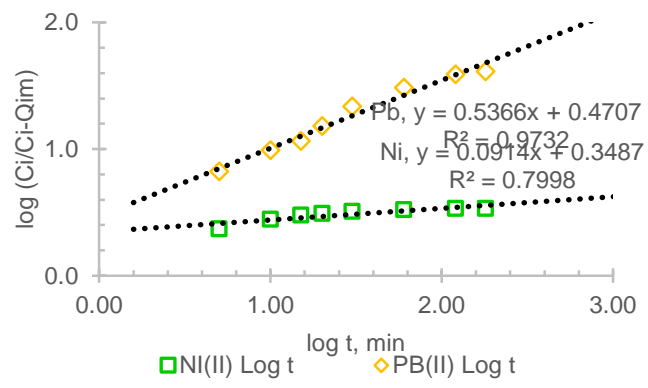

Figure 5(e) Kinetic Study of Bangham's Theory (Pore Diffusion) of $\mathrm{Pb}$ (II) and $\mathrm{Ni}(\mathrm{II})$ for $20 \mathrm{mg} / \mathrm{L}$

\subsection{Isotherm Study}

Langmuir and Freundlich isotherms are models that are widely used to illustrate the relationship between the adsorbed and the free metal ions when it achieved equilibrium [20]. According to Langmuir model, the biosorption process happened in a homogeneous distribution and without any interaction with adsorbed metal ions.
Meanwhile, Freundlich Isotherm assumes that the biosorption process takes place on heterogeneous surfaces. The biosorption performance are directly dependent on the metal ions concentration [15, 25]. The linear form of Langmuir and Freundlich isotherm equation can be represented by using equations (9) and (10) respectively:

$$
\begin{gathered}
\frac{1}{\mathrm{Q}_{\mathrm{e}}}=\left[\frac{1}{\mathrm{~K}_{\mathrm{L}}\left(\mathrm{Q}_{\mathrm{m}}\right)}\right] \frac{1}{\mathrm{C}_{\mathrm{e}}}+\frac{1}{\mathrm{Q}_{\mathrm{m}}} \\
\log Q_{e}=\log K_{F}=\frac{1}{n} \log C_{e}
\end{gathered}
$$

Where $Q_{e}$ represents the number of metal ions adsorbed per unit mass of biosorbent $(\mathrm{mg} / \mathrm{g})$ and $\mathrm{C}_{e}$ is the equilibrium concentration of metal ions ( $\mathrm{mg} / \mathrm{L}$ ). When the $1 / Q_{e}$ is plotted against $1 / C_{e}$, the linear lines with a slope of $K_{L}(L / m g)$ and c-intercept of $Q_{m}(\mathrm{mg} / \mathrm{g})$ is obtained (Figure 6(a)). These Langmuir constants are related to the biosorption capacity and rate of biosorption respectively [20].

Meanwhile, $\mathrm{K}_{\mathrm{F}}$ and $\mathrm{n}$ are the Freundlich constants which indicate the biosorption capacity of biosorbent and intensity respectively, can be acquired from the slope and $c$-intercept of plots log $Q_{e}$ versus log $C_{e}$ (Figure 6(b) [14, 20]. Khosravihaftkhany et al. [16] pointed out that the lowest values of $K_{F}$ and $n$ will give a higher bond strength and energy between metal ions ion and active sites respectively. When compared with previous researches, $Q_{\max }$ for BM are better than others adsorbent eventhough some of the $Q_{\text {max }}$ are greater than BM. For instance, $Q_{\max }$ of BM for $\mathrm{Pb}$ (II) metal ions are greater than other adsorbent but for NI (II) metal ions, some of the adsorbent are stated greater than BM.

Temkin and Dubinin-Radushkevich (D-R) isotherms are models that are used to analyse the biosorption equilibrium between adsorbate-sorbent interactions.

\begin{tabular}{|c|c|c|c|c|c|c|c|c|c|c|c|c|c|c|}
\hline \multirow{2}{*}{$\begin{array}{l}\text { METAL } \\
\text { IONS }\end{array}$} & \multicolumn{3}{|c|}{ LANGMUIR } & \multicolumn{4}{|c|}{ FREUNDLICH } & \multicolumn{3}{|c|}{ TEMKIN } & \multicolumn{4}{|c|}{ D-R } \\
\hline & $\mathbf{Q}_{m}$ & $\mathrm{~K}_{\mathrm{L}}$ & $\mathrm{R}^{2}$ & $1 / n$ & $\mathbf{n}$ & $\mathrm{K}_{\mathrm{F}}$ & $\mathbf{R}^{2}$ & $\mathbf{b}_{\mathrm{T}}$ & $\mathbf{K}_{\mathrm{T}}$ & $\mathbf{R}^{2}$ & $\mathbf{Q}_{\mathrm{m}}$ & $\beta$ & $\Delta \mathrm{E}_{\mathrm{a}}$ & $\mathbf{R}^{2}$ \\
\hline & $(\mathrm{mg} / \mathrm{g})$ & $(\mathrm{L} / \mathrm{mg})$ & & & & $(\mathrm{L} / \mathrm{mg})$ & & $(\mathrm{kJ} / \mathrm{mol})$ & $(1 / g)$ & & $(\mathrm{mg} / \mathrm{g})$ & & $(\mathrm{kJ} / \mathrm{mol})$ & \\
\hline $\mathrm{NI}(\mathrm{II})$ & 3.53 & 5.50 & 0.9273 & 0.277 & 3.614 & 2.36 & 0.9973 & 3.606 & 49.55 & 0.9633 & 3.50 & 0.0305 & 23.18 & 0.8248 \\
\hline PB(II) & 10.93 & 1.67 & 0.8283 & 0.453 & 2.209 & 5.48 & 0.8260 & 1.489 & 32.04 & 0.9497 & 6.94 & 0.0428 & 16.52 & 0.9276 \\
\hline
\end{tabular}

Table 3 Comparison of Isotherms study of Langmuir, Freundlich, Temkin and D-R constants for Pb(II) and Ni(II) Metal ions

Temkin isotherm is a model that describes the heat of biosorption ( $\left.\Delta \mathrm{H}_{\mathrm{ads}}\right)$ in the active sites decrease with the increasing coverage layer of metal ions on the biosorbent surfaces. D-R isotherm is normally used to portray the biosorption mechanism on both heterogeneous and homogeneous surfaces on the biosorbent with Gaussian energy distribution. The linear form of Temkin and D-R isotherm equations are presented in the following equation (11) and (12):

$$
\begin{aligned}
& Q_{e}=\frac{R T}{b_{T}} \ln K_{T}+\frac{R T}{b_{T}} \ln C_{e} \\
& \ln Q_{e}=\ln Q_{m}-\beta \varepsilon^{2}
\end{aligned}
$$

Where $\varepsilon$ can be correlated with equation (13):

$$
\varepsilon=R T \ln \left(1+\frac{1}{C_{e}}\right)
$$

Where the constant values of $\mathrm{R}$ and $\mathrm{T}$ represent the gas constant $(8.314 \mathrm{~J} / \mathrm{mol} \mathrm{K})$ and absolute temperature $(K)$ respectively. The Temkin constant, bT that is related to the heat of biosorption $(\mathrm{kJ} / \mathrm{mol})$ indicates the biosorption potential of biosorbent, while $\mathrm{K}_{\mathrm{T}}$ is a biosorption capacity.

These constants can be calculated from the cintercept and slopes of linear $Q_{e}$ against In $C_{e}$ as shown in Figure 6(c). Meanwhile, $\beta$ and $Q_{m}$ are the D$R$ rate constants that depicts of the free energy of biosorption $\left(\mathrm{mol}^{2} \mathrm{~K} / \mathrm{J}^{2}\right)$, and theoretical saturation capacity. 


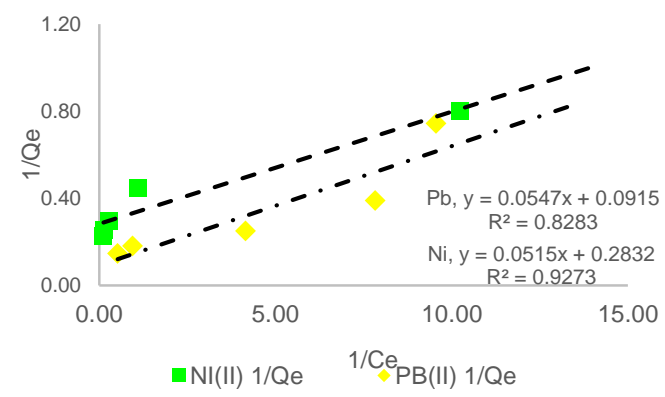

Figure 6(a) Langmuir Isotherm plot for Biosorption of Ni (II) and $\mathrm{Pb}$ (II) lons by Biosorbent Mixture

The plot on InQe against $\varepsilon^{2}$ (Figure 6(d) enables these constants to be determined from the respective slope c-intercept. The equation (14) indicates that the Polanyi potential is used to calculate the mean of energy $\left(E_{a}\right)$ from $\beta$.

$$
E_{a}=\frac{1}{\sqrt{2} \beta}
$$

Atkins and Paula [26] claim that if the values of $E_{a}$ are between 1-8 kJ/mol, it indicates that physical biosorption involved in biosorption process. Furthermore, the range between $8-16 \mathrm{~kJ} / \mathrm{mol}, 20-40$ $\mathrm{kJ} / \mathrm{mol}$ and greater than $40 \mathrm{~kJ} / \mathrm{mol}$ also show the biosorption process involved ion exchange, chemical biosorption, and strong chemical biosorption respectively.

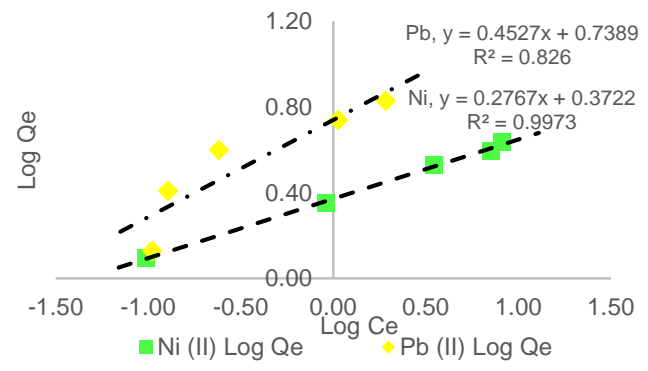

Figure 6(b) Freundlich Isotherm plot for Biosorption of $\mathrm{Ni}(\mathrm{II})$ and $\mathrm{Pb}$ (II) lons by Biosorbent Mixture

All the $\mathrm{R}^{2}$ values and the constants obtained from the four isotherm models applied in the biosorption of $\mathrm{Ni}$ (II) and $\mathrm{Pb}$ (II) are summarised in Table 3. In this research, the biosorption process took place at $25^{\circ} \mathrm{C}$ or $298 \mathrm{~K}$ of room temperature. Table 3 illustrates that the mean of energy, Ea values for $\mathrm{Ni}$ (II) and $\mathrm{Pb}$ (II) ions were between 8-16 kJ/mol and 20-40 kJ/mol respectively. These ranges of values indicate that the $\mathrm{Ni}$ (II) ions biosorption process involves the chemical biosorption and $\mathrm{Pb}(\mathrm{II})$ ions involves stronger chemical biosorption.

As seen in Table 3, it can be observed that the Freundlich, and Temkin isotherms gave the highest $\mathrm{R}^{2}$ values for $\mathrm{Ni}$ (II) that greater than 0.95 , showing that the $\mathrm{Ni}$ (II) ions were best described by these two models. As for $\mathrm{Pb}$ (II) ions, Temkin and D-R isotherm models exhibited good fit as the rate of controlling mechanism with the $R^{2}$ value is higher than 0.90 . The higher $\mathrm{R}^{2}$ values depict that biosorption process of $\mathrm{Ni}$ (II) occurred on a heterogeneous layer of active sites while $\mathrm{Pb}$ (II) ions happened in both heterogeneous and homogeneous. As presented in Table 3, the maximum monolayer capacities, $Q_{m}$ of Langmuir isotherm was slightly higher than $\mathrm{D}-\mathrm{R}$ isotherm for $\mathrm{Ni}$ (II) and $\mathrm{Pb}$ (II). Furthermore, the $1 / \mathrm{n}$ values showed $\mathrm{a}$ normal biosorption if the values were below 1.0 and caused the $K_{F}$ value to increase with an increasing initial concentration. However, if the $1 / n$ value was above 1.0, it indicated that the cooperative biosorption occurred and caused the $K_{F}$ values to decrease $[25,27]$. Overall, the $1 / \mathrm{n}$ values for $\mathrm{Ni}$ (II) and $\mathrm{Pb}$ (II) ions were less than 1.0 which showed that the metal ions biosorption was a normal biosorption.

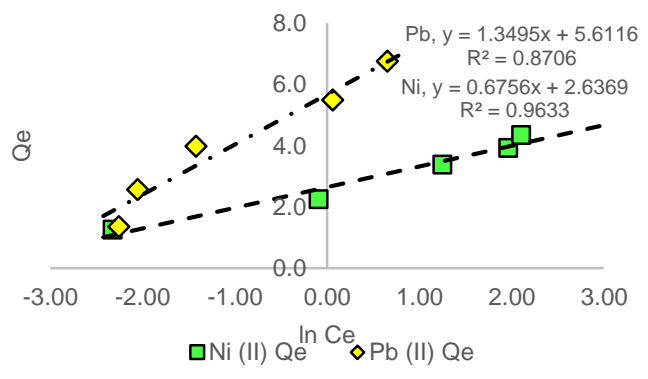

Figure 6(c) Temkin Isotherm plot for Biosorption of Ni (II) and $\mathrm{Pb}(\mathrm{II})$ ions by Biosorbent Mixture

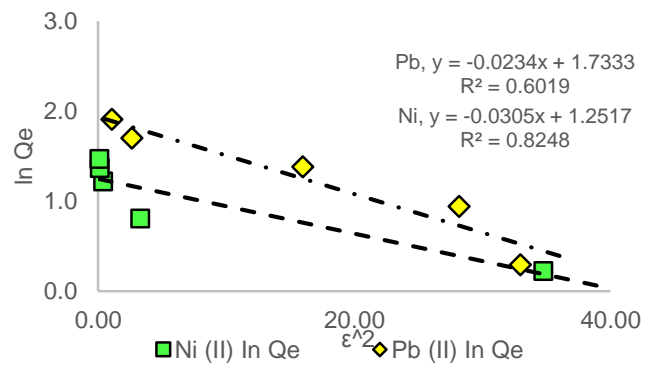

Figure 6(d) Dubinin-Radushkevich (D-R) Isotherm plot for Biosorption of $\mathrm{Ni}$ (II) and $\mathrm{Pb}$ (II) ions by Biosorbent Mixture

\subsection{CONCLUSION}

In this research, Biosorbent Mixture (BM) have been recognised to have higher biosorption performance in removing metal ions. The results showed that the biosorption efficiency was directly dependent on the experimental conditions. The biosorption performance increased as the initial $\mathrm{pH}$ or contact time increases. In the kinetic study, Pseudo-SecondOrder model exhibited a good fit for both metal biosorption with highly agreeable values of $Q_{e}$ (calculation) and $Q_{e}$ (experimental). These metal ions have different isotherm models represented by their rate of controlling mechanism. It can be concluded that Freundlich, Temkin, and Langmuir isotherms can be applied successfully for the $\mathrm{Ni}$ (II) ions whereas $\mathrm{Pb}$ (II) ions are found to comply to the D-R and Temkin isotherms.

\section{Acknowledgement}

The author has acknowledged the Universiti Teknologi MARA Sarawak, Campus Samarahan 2, Sarawak for the approval of "Dana Kecermerlangan UiTM 
Sarawak" [Project Code: 600-RMU/DANA 5/3 (5/2016)] for financial support to buy all the chemical items.

\section{References}

[1] Wang, J., \& Chen, C. 2014. Chitosan-based Biosorbents: Modification and Application for Biosorption of Heavy Metals and Radionuclides. Bioresource Technology. 160: 129-141.

[2] Zhang, L., Zeng, Y., \& Cheng, Z. 2016. Removal of Heavy Metal Ions Using Chitosan and Modified Chitosan: A Review. Journal of Molecular Liquids. 214: 175-191.

[3] Ujih, M. B., Mohamadin, M. I., Asli, M. A., \& Mohamed, B. N. 2017. Bioadsorption of Multiple Heavy Metal lons by Rhizophora apiculate sp. and Elaesis guineensis sp./MB Nicodemus Uji et al. Scientific Research Journal. 14(1): 1627.

[4] Fuadi, F. A., Nor-Azemi, S. N. I., \& Syed-Hassan, S. S. A. 2014. Biosorption Capacity of Nickel (II) and Cobalt (II) Ions from Aqueous Solutions by Oil Palm Waste and Sawdust. Advanced Materials Research. 911: 322-325.

[5] Johari, I. S., Yusof, N. A., Haron, M. J., \& Nor, S. M. M. 2013. Preparation and Characterization of Poly (ethyl hydrazide)Grafted Oil Palm Empty Fruit Bunch Fibre for the Removal of $\mathrm{Cu}$ (II) Ions from an Aqueous Environment. Molecules. 18(7): 8461-8472.

[6] Liu, R., Song, Y., \& Tang, H. 2013. Application of the Surface Complexation Model to the Biosorption of $\mathrm{Cu}$ (II) and $\mathrm{Pb}$ (II) ions onto Pseudomonas pseudoalcaligenes Biomass. Biosorption Science \& Technology. 31 (1): 1-16.

[7] Baysal, A., Ozbek, N., \& Akman, S. 2013. Determination of Trace Metals in Waste Water and Their Removal Processes. In Waste Water-Treatment Technologies and Recent Analytical Developments. In Tech.

[8] Gupta, R., Ahuja, P., Khan, S., Saxena, R. K., \& Mohapatra, H. 2000. Microbial Biosorbents: Meeting Challenges of Heavy Metal Pollution in Aqueous Solutions. CURRENT SCIENCE-BANGALORE. 78(8): 967-973.

[9] Macek, T., \& Mackova, M. 2011. Potential of Biosorption Technology. Microbial Biosorption of Metals. Springer Netherlands. 7-17.

[10] Das, N., Vimala, R., \& Karthika, P. 2008. Biosorption of Heavy Metals-An Overview. Indian J Biotechnol. 7: 159-169.

[11] Seey, T. L., \& Kassim, M. J. N. M. 2012a. Characterization of Mangrove Bark as a Potentially Low- Cost Adsorbent for Reactive Dye Removal from Aqueous Solutions: Equilibrium, Mechanisms, and Kinetics. International Journal of Pure and Applied Sciences and Technology. 9(1).

[12] Oo, C. W., \& Jain, K. 2007.Removal of Cu2+ from Aqueous Solution by Rhizophora apiculata Mangrove TanninsBased. International Conference on Chemical Sciences.

[13] Rani, S., \& Mahajan, R. K. 2016. Equilibrium, Kinetics and Thermodynamic Parameters for Adsorptive Removal of Dye Basic Blue 9 by Groundnut Shells and Eichhornia. Arabian Journal of Chemistry. 9: S1464-S1477.

[14] Malik, R., \& Dahiya, S. 2017. An Experimental and Quantum Chemical Study of Removal of Utmostly Quantified Heavy Metals in Wastewater Using Coconut Husk: A Novel
Approach to Mechanism. International Journal of Biological Macromolecules. 98: 139-149.

[15] Sadeek, S. A., Negm, N. A., Hefni, H. H., \& Wahab, M. M. A. 2015. Metal Biosorption by Agricultural Biosorbents: Biosorption Isotherm, Kinetic and Biosorbents Chemical Structures. International Journal of Biological Macromolecules. 81: 400-409

[16] Khosravihaftkhany, S., Morad, N., Teng, T. T., Abdullah, A. Z. \& Norli, I. 2013. Biosorption of $\mathrm{Pb}$ (II) and Fe (III) from Aqueous Solutions Using Oil Palm Biomasses as Adsorbents. Water Air, \& Soil Pollution. 224(3): 1-14.

[17] Nor-Azemi, S. N. I., Fuadi, F. A., \& Syed-Hassan, S. S. A. 2014 Effect of Pretreatment on Biosorption of Nickel by Oil Palm Mesocarp Fiber. Advanced Materials Research. 906: 131136). Trans Tech Publications

[18] Oo, C. W., Kassim, M. J., \& Pizzi, A. 2009. Characterization and Performance of Rhizophora apiculata Mangrove Polyflavonoid Tannins in the Biosorption of Copper (II) and Lead (II). Industrial Crops and Products. 30(1): 152-161.

[19] Hossain, M. A., Ngo, H. H., Guo, W. S., \& Nguyen, T. V. 2012. Palm Oil Fruit Shells as Biosorbent for Copper Removal from Water and Wastewater: Experiments and Sorption Models. Bioresource Technology. 113: 97-101.

[20] Patescu, R. E., Simonescu, C. M., Busuioc, L. T., Onose, C., \& Melinescu, A. 2016. Simultaneous Removal of Lead (II), Nickel (II), Zinc (II) and Copper (II) from Aqueous Solutions by Nano-hydroxyapatite Synthesized by Microwave Field. Environments. 9: 11.

[21] Ho, Y. S., and Ofomaja, A. E. 2006. Kinetic Studies of Copper Ion Biosorption on Palm Kernel Fibre. Journal of Hazardous Materials. 137(3): 1796-1802.

[22] Tan, I. A. W., Ahmad, A. L., \& Hameed, B. H. 2009 Biosorption Isotherms, Kinetics, Thermodynamics and Desorption Studies of 2, 4, 6-trichlorophenol on Oil Palm Empty Fruit Bunch-based Activated Carbon. Journal of Hazardous Materials. 164(2): 473-482.

[23] Ekmes`čic, B. M., Maksin, D. D., Markovic, J. P., Vukovic, Z. M., Hercigonja, R. V., Nastasovic, A. B., \& Onjia, A. E. 2015. Recovery of Molybdenum Oxyanions Using Macroporous Copolymer Grafted With Diethylenetriamine. Arabian Journal of Chemistry.

[24] Chakrapani, C. H., Babu, C., Vani, K. N. K., \& Rao, K. S. 2010 Biosorption Kinetics for the Removal of Fluoride from Aqueous Solution by Activated Carbon Adsorbents Derived from the Peels of Selected Citrus Fruits. Journal of Chemistry. 7(S1): S419-S427.

[24] Rani, S., \& Mahajan, R. K. 2012. Equilibrium, Kinetics and Thermodynamic Parameters for Adsorptive Removal of Dye Basic Blue 9 by Ground Nut Shells and Eichhornia. Arabian Journal of Chemistry. 9: S1 464-s1477

[25] Dada, A. O., Olalekan, A. P., Olatunya. A. M., \& Dada, O. 2012. Langmuir, Freundlich, Temkin and DubininRadushkevich Isotherms Studies of Equilibrium Sorption of Zn2+ unto Phosphoric Acid Modified Rice Husk. IOSR Journal of Applied Chemistry. 3(1): 38-45

[26] P. Atkins and J de Paula. 2010. Physical Chemistry. $9^{\text {th }}$ ed. New York, Oxford University Press.

[27] Ismail, M. G. B. H., Weng, C. N., Rahman, H. A., \& Zakaria N. A. 2013. Freundlich Isotherm Equastion in determining Effectiveness a low Cost Adsorbent to Heavy Metal Removal in Wastewaster (Leachate) at Teluk Kitang Landfill, Pangkalan Chepa, Kelantan, Malaysia. Journal of Geography and Earth Science. 1(1): 01-08. 